Prepared in cooperation with Milwaukee Metropolitan Sewerage District

\title{
Stream Geomorphic and Habitat Data from a Baseline Study of Underwood Creek, Wisconsin, 2012
}
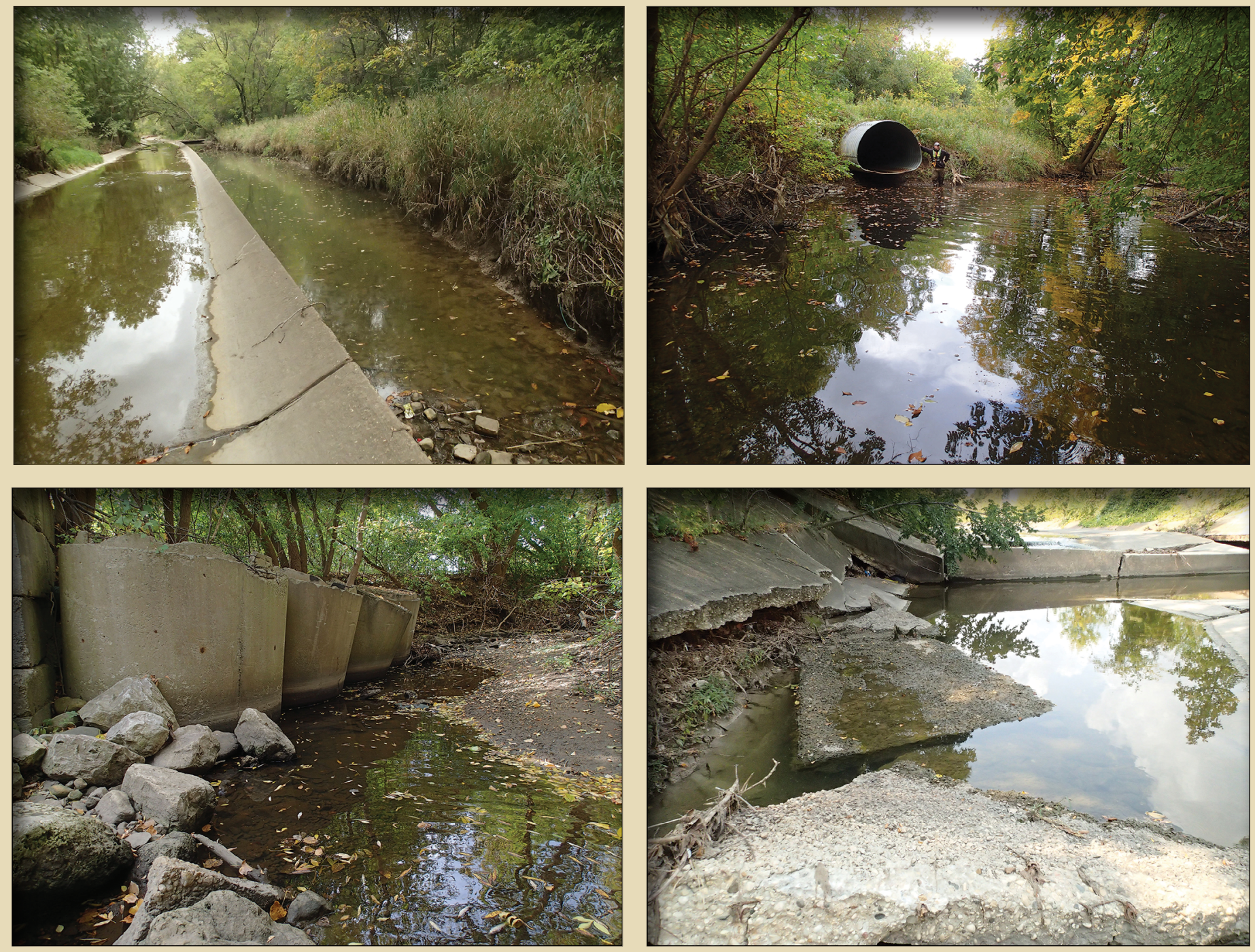

Data Series 947

U.S. Department of the Interior

U.S. Geological Survey 
Cover photos (clockwise from top left). Scour and erosion outside of the concrete lined Underwood Creek, September 17, 2012 (photo taken by Nicolas H. Buer); large outfall above scour pool upstream of confluence of Underwood Creek and Menomonee River, September 27, 2012 (photo taken by James D. Blount); concrete bank stabilizers along Underwood Creek, September 27, 2012 (photo taken by James D. Blount); failed concrete bed of Underwood Creek, September 17, 2012 (photo taken by Nicolas H. Buer). 


\section{Stream Geomorphic and Habitat Data from a Baseline Study of Underwood Creek, Wisconsin, 2012}

By Benjamin M. Young, Faith A. Fitzpatrick, and James D. Blount

Prepared in cooperation with Milwaukee Metropolitan Sewerage District

Data Series 947 


\title{
U.S. Department of the Interior SALLY JEWELL, Secretary
}

\section{U.S. Geological Survey \\ Suzette M. Kimball, Acting Director}

\author{
U.S. Geological Survey, Reston, Virginia: 2015
}

For more information on the USGS - the Federal source for science about the Earth, its natural and living resources, natural hazards, and the environment—visit http://www.usgs.gov or call 1-888-ASK-USGS.

For an overview of USGS information products, including maps, imagery, and publications, visit http://www.usgs.gov/pubprod/.

Any use of trade, firm, or product names is for descriptive purposes only and does not imply endorsement by the U.S. Government.

Although this information product, for the most part, is in the public domain, it also may contain copyrighted materials as noted in the text. Permission to reproduce copyrighted items must be secured from the copyright owner.

Suggested citation:

Young, B.M., Fitzpatrick, F.A., Blount, J.D., 2015, Stream geomorphic and habitat data from a baseline study of Underwood Creek, Wisconsin, 2012: U.S. Geological Survey Data Series 947, 14 p., plus data files, http://dx.doi.org/10.3133/ds947.

ISSN 2327-638X (online) 


\section{Contents}

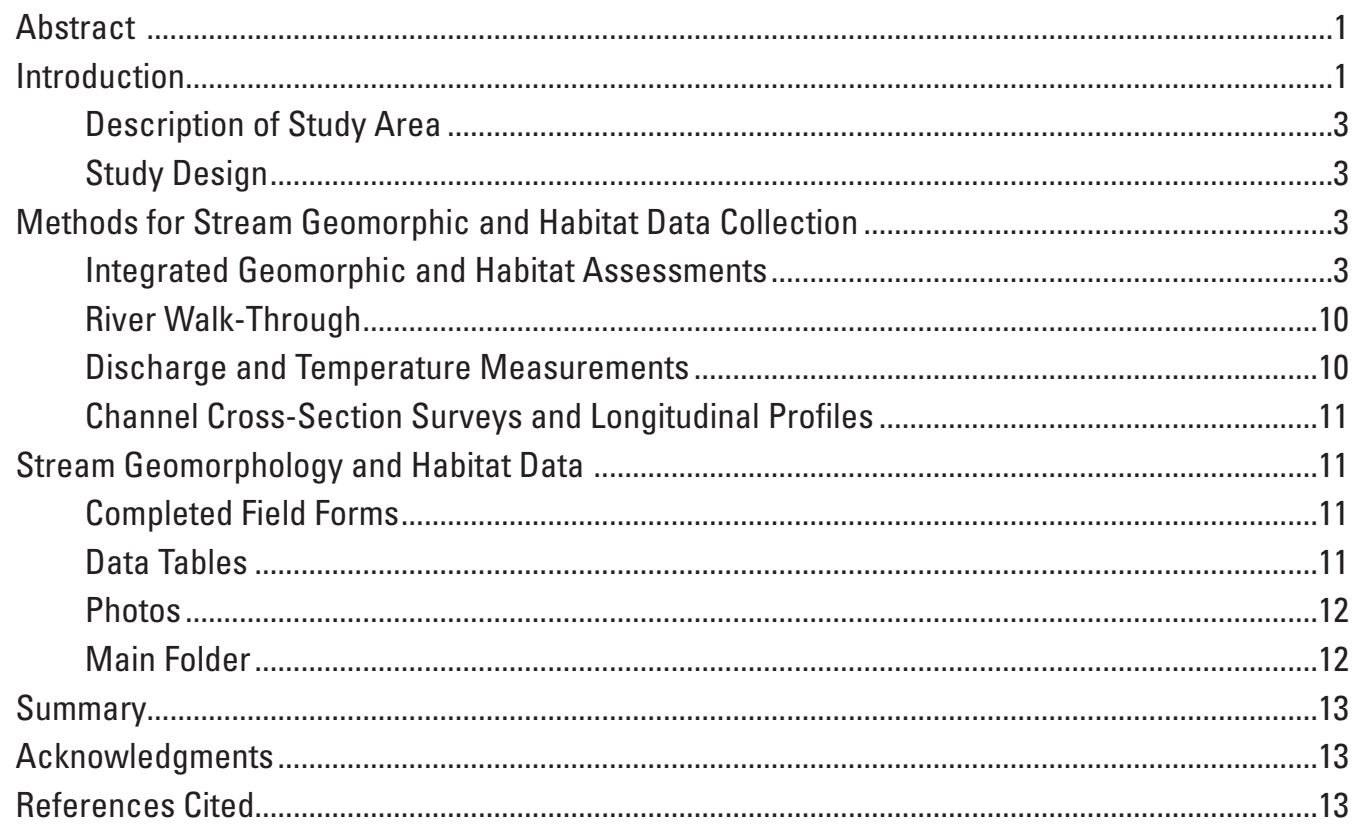

\section{Data Downloads}

A subset of habitat-specific data collected during the baseline study can be retrieved through USGS BioData https://aquatic.biodata.usgs.gov/landing.action.

Data downloads available at http://dx.doi.org/10.3133/ds947.

\section{Figures}

1. Map showing reach locations included in the Underwood Creek geomorphic and habitat assessments, the Underwood Creek and Menomonee River streamgage, and the extent of the river walk-through.

2. Hydrographs of $(A)$ Underwood Creek and $(B)$ Menomonee River with overlays of time periods when geomorphic and habitat assessments, river walk-through, and channel cross-section surveys and longitudinal profiles were completed.....

3. Photographic comparison of flow conditions at Underwood Creek site 1 (0408708562) at time of geomorphic and habitat site assessment $(A)$ on August 30, 2012, at time of river walk-through, and (B) on September 27, 2012....6 


\section{Tables}

1. List of eight reaches included in the Underwood Creek geomorphic and habitat assessment study, 2012. These reaches included an integrated geomorphic and habitat assessment, discharge and water temperature measurements, and surveyed channel cross sections and longitudinal profiles

2. Detailed geomorphic measurements collected in addition to the National Water Quality Assessment protocol for Milwaukee Metropolitan Sewerage District geomorphic and habitat assessment at the eight sampled reaches along Underwood Creek and the Menomonee River.

3. Rapid geomorphic assessment measurements collected in addition to the National Water Quality Assessment protocol for Milwaukee Metropolitan Sewerage District geomorphic and habitat assessment at the eight sampled reaches along Underwood Creek and the Menomonee River.

4. Detailed geomorphic measurements collected in addition to the National Water Quality Assessment Program protocol for Milwaukee Metropolitan Sewerage District geomorphic and habitat assessment at the eight sampled reaches along Underwood Creek and the Menomonee River...

5. Substrate related measurements collected at the 11 transects and

10 sub transects along the eight sampled reaches as part of pebble counts.

\section{Conversion Factors}

International System of Units to Inch/Pound

\begin{tabular}{lll}
\hline \multicolumn{1}{c}{ Multiply } & By & \multicolumn{1}{c}{ To obtain } \\
\hline centimeter $(\mathrm{cm})$ & Length & \\
millimeter $(\mathrm{mm})$ & 0.3937 & inch (in.) \\
meter $(\mathrm{m})$ & 0.03937 & inch (in.) \\
kilometer $(\mathrm{km})$ & 3.281 & foot (ft) \\
meter $(\mathrm{m})$ & 0.6214 & mile (mi) \\
& 1.094 & yard $(\mathrm{yd})$ \\
\hline square meter $\left(\mathrm{m}^{2}\right)$ & Area & \\
square kilometer $\left(\mathrm{km}^{2}\right)$ & 0.0002471 & acre \\
square meter $\left(\mathrm{m}^{2}\right)$ & 247.1 & acre \\
square kilometer $\left(\mathrm{km}^{2}\right)$ & 10.76 & square foot $\left(\mathrm{ft}^{2}\right)$ \\
\hline & 0.3861 & square mile $\left(\mathrm{mi}^{2}\right)$ \\
\hline cubic meter $\left(\mathrm{m}^{3}\right)$ & Volume & \\
cubic meter $\left(\mathrm{m}^{3}\right)$ & 264.2 & gallon $(\mathrm{gal})$ \\
cubic meter $\left(\mathrm{m}^{3}\right)$ & 35.31 & cubic foot $\left(\mathrm{ft}^{3}\right)$ \\
\hline & 1.308 & cubic yard $\left(\mathrm{yd}^{3}\right)$ \\
\hline cubic meter per second $\left(\mathrm{m}^{3} / \mathrm{s}\right)$ & Flow rate & \\
\hline
\end{tabular}




\section{Datum}

Vertical coordinate information is referenced to the North American Vertical Datum of 1988 (NAVD 88).

Horizontal coordinate information is referenced to the World Geodetic System 1984 (WGS84).

Altitude, as used in this report, refers to distance above the vertical datum.

\section{Abbreviations}

$\begin{array}{ll}\text { GIS } & \text { geographic information system } \\ \text { GPS } & \text { global positioning system } \\ \text { MASL } & \text { meters above sea level } \\ \text { MMSD } & \text { Milwaukee Metropolitan Sewerage District } \\ \text { NAWQA } & \text { National Water-Quality Assessment } \\ \text { PDF } & \text { portable document format } \\ \text { RTN } & \text { real-time network } \\ \text { USGS } & \text { U.S. Geological Survey }\end{array}$

\section{Acknowledgments}

The authors thank Nic Buer (U.S. Geological Survey) for assistance with data collection, Dan Mossing (University of Wisconsin-Madison undergraduate student) for data processing and analysis, and Molly Breitmün (U.S. Geological Survey) for data and content reviews. Reviews by Michelle Lutz (U.S. Geological Survey) and Thomas Chapman (Milwaukee Metropolitan Sewerage District) helped to improve the manuscript, and their time and comments are greatly appreciated. 



\title{
Stream Geomorphic and Habitat Data from a Baseline Study of Underwood Creek, Wisconsin, 2012
}

\author{
By Benjamin M. Young, Faith A. Fitzpatrick, and James D. Blount
}

\section{Abstract}

Geomorphic and habitat data were collected along Underwood Creek as part of a larger study of stream waterquality conditions in the greater Milwaukee, Wisconsin, area. The data were collected to characterize baseline physical conditions in Underwood Creek prior to a potential discharge of wastewater return flow to the stream from the city of Waukesha, Wis. Geomorphic and habitat assessments were conducted in the summer and fall of 2012 by the U.S. Geological Survey (USGS) in cooperation with the Milwaukee Metropolitan Sewerage District. The assessments used a transect based, reach scale assessment at a total of eight reaches - six reaches along Underwood Creek and two reaches along the Menomonee River upstream and downstream of its confluence with Underwood Creek. The reach scale assessment was an updated version of the USGS National Water Quality Assessment Program habitat assessment integrated with an intensive geomorphic assessment. Channel cross sections and longitudinal profiles were surveyed along each of the eight reaches, and discharge and water temperature were measured. Additionally, a geomorphic river walk-through was completed along a 10-kilometer reach that spanned the individual assessment reaches and the sections of channel between them. The assessments and river walk-through described channel and bank stability, channel shape and size, and sediment and riparian conditions along these areas of Underwood Creek and the Menomonee River. Since the time of the data collection, focus has turned to other Lake Michigan tributary watersheds for possible Waukesha return-flow discharges; however, the data collected for this effort remains a valuable asset for the baseline characterization, design, and prioritization of planned stream rehabilitation activities in Underwood Creek. The data files presented in this report include a variety of formats including geographic information system files, spreadsheets, photos, and scans of field forms.

\section{Introduction}

A study was undertaken by the U.S. Geological Survey (USGS) to characterize baseline geomorphology and physical habitat conditions of Underwood Creek prior to a possible discharge of wastewater effluent from the city of Waukesha, Wisconsin (fig. 1). The study is part of a larger cooperative program between the USGS and the Milwaukee Metropolitan Sewerage District (MMSD) that includes assessment and monitoring of water-quality conditions in the greater Milwaukee, Wis., metropolitan area. The potential discharge to Underwood Creek was part of an initial proposal by the city of Waukesha in May 2010 to withdraw water from Lake Michigan for public water supply and subsequently replace it with wastewater discharge back to the watershed of Lake Michigan in accordance with the Great Lakes St. Lawrence River Basin Water Resources Compact and Wisconsin State Statutes section 281.346 (CH2M Hill, 2013).

Geomorphic and habitat assessments were conducted in the summer and fall of 2012 to document baseline conditions. The assessments concentrated on channel and bank stability, channel shape and size, as well as sediment and riparian conditions along Underwood Creek from above the input of the proposed Waukesha return flow to its confluence with the Menomonee River. Reaches along the Menomonee River upstream and downstream of the Underwood Creek confluence were also included. A secondary purpose of the study was to document baseline conditions prior to possible stream rehabilitation work planned by MMSD.

The assessment included four basic components:

- An updated (with respect to Fitzpatrick and others, 1998) transect based geomorphic and habitat assessment at six reaches along Underwood Creek and two reaches along the Menomonee River (fig. 1), including a pebble count, large woody debris count, pools, bank erosion measurements, depositional bars, and georeferenced photos 


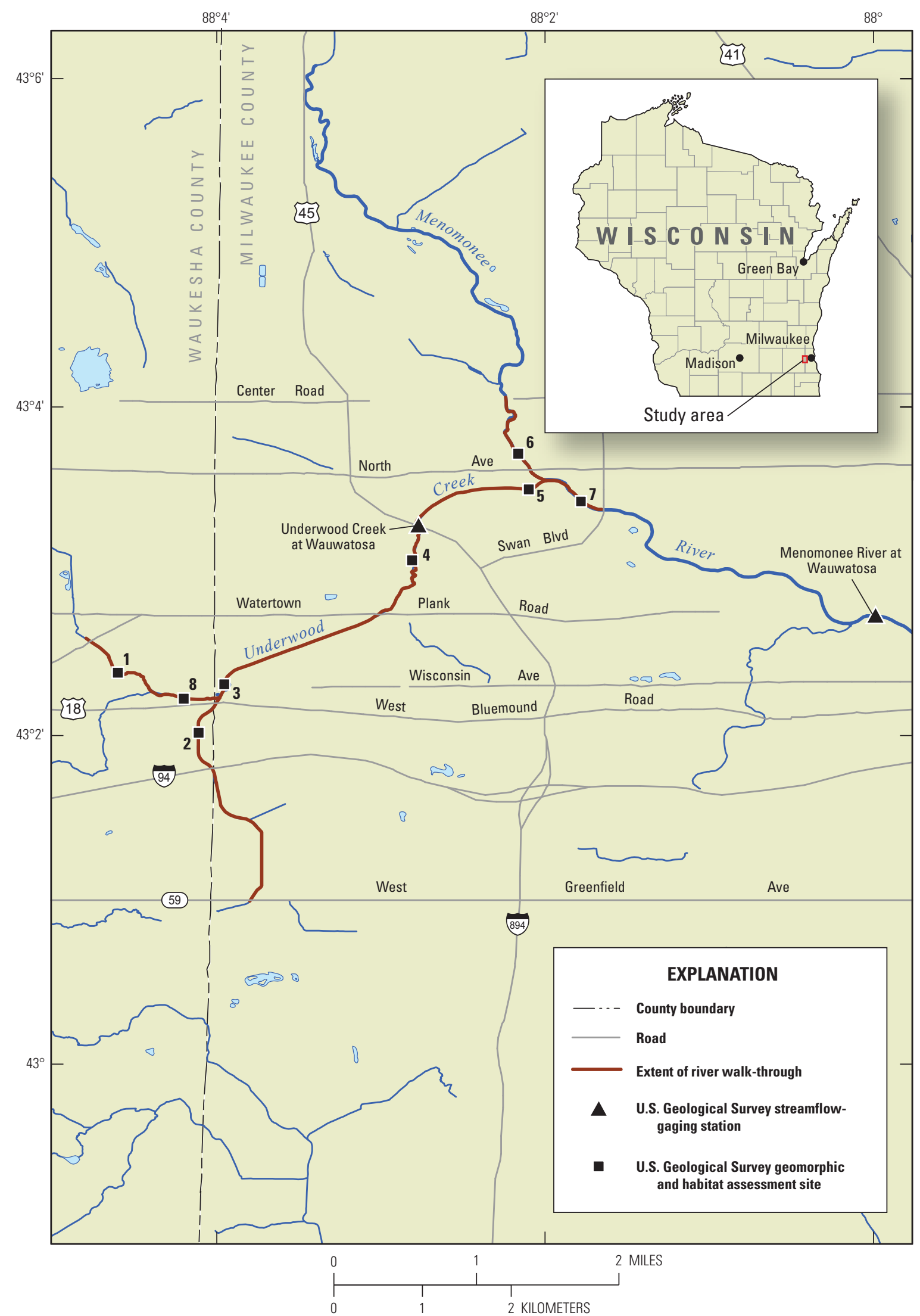

Figure 1. Reach locations included in the Underwood Creek geomorphic and habitat assessments, the Underwood Creek and Menomonee River streamgage, and the extent of the river walk-through. 
- A reconnaissance-level river walk-through of approximately 10 kilometers $(\mathrm{km})$ along Underwood Creek and the Menomonee River (upstream and downstream of the Underwood Creek confluence), including georeferenced photos and locations of outfalls, failed or failing structures and banks, bed controls, channel crossings, and noticeable locations of deposition and scour

- Low-flow discharge and water temperature measurements at the eight geomorphic and habitat assessment reaches

- Topographic surveys including channel cross sections and longitudinal profiles at the eight geomorphic and habitat assessment reaches.

\section{Description of Study Area}

Underwood Creek drains approximately 47 square kilometers and flows into the Menomonee River near Wauwatosa, Wis. The stream is in the Western Lake Michigan Drainage Basin and drains portions of the cities of Brookfield, Milwaukee, New Berlin, Wauwatosa, and West Allis, the town of Brookfield, and the village of Elm Grove. More than 80 percent of the watershed is developed land (Thomas and others, 2007). Most of Underwood Creek is concrete lined and flooding is a problem in upstream areas. At the USGS streamgage (04087088), the stream has an annual mean discharge of 0.43 cubic meters per second $\left(\mathrm{m}^{3} / \mathrm{s}\right)$, a 7 -day minimum flow of $0.0 \mathrm{~m}^{3} / \mathrm{s}$, and an instantaneous peak flow of $212 \mathrm{~m}^{3} / \mathrm{s}$ from water years 1975-2012 (U.S. Geological Survey, 2013).

\section{Study Design}

The study design was based on the need to document possible physical changes in habitat conditions in Underwood Creek and the Menomonee River resulting from increases in flow associated with the addition of wastewater discharge from the city of Waukesha. These changes may be beneficial by providing more flow during dry periods or detrimental by possibly increasing bank erosion during runoff periods. The design was based on the integration of intensive transect-based geomorphic and habitat assessments for eight 150-m reaches (table 1) overlain on a river walk-through that extended between and beyond the intensive reaches for a total coverage of approximately $10 \mathrm{~km}$. The eight geomorphic and habitat assessment reaches were selected to represent a variety of channel conditions (natural, restored, concrete lined) and flow inputs. This nested design, incorporating unaffected and potential affected reaches of Underwood Creek, is necessary to distinguish the effects of additional Waukesha discharge from other changes that happen regardless of this additional discharge, such as bank erosion from a large flood.
All data were collected during summer and fall lowflow conditions spanning from late August to late September 2012 (fig. 2). The geomorphic and habitat assessments were completed between late August and mid-September. The topographic surveys of channel cross sections and longitudinal profiles along with the river walk-through continued into late September. Low-flow conditions were preferentially selected, but antecedent conditions (time since last runoff event) affected the amount of water in Underwood Creek. This is evident at site 1 (0408708562), upstream of the possible Waukesha return input point, where on August 30 during the geomorphic and habitat assessment (as well as during the topographic survey) there was standing water in-channel, but a condition of no flow was observed during the river walk-through following a longer time period after the last runoff (fig. 3). Both days had a discharge of approximately $0.05 \mathrm{~m}^{3} \mathrm{~s}$ at the Underwood Creek streamgage $3.64 \mathrm{~km}$ downstream of site 1 (fig. 2).

\section{Methods for Stream Geomorphic and Habitat Data Collection}

Geomorphic and habitat data were collected at two main spatial scales - at eight representative 150-meter (m) reaches and a reconnaissance river walk-through of approximately $10 \mathrm{~km}$ extending between and beyond the reaches (fig. 1, table 1)

\section{Integrated Geomorphic and Habitat Assessments}

An updated version of the USGS National Water-Quality Assessment (NAWQA) habitat protocol was developed for urban streams and evaluating the success of stream restoration activities in the MMSD area (Fitzpatrick and others, 1998). This updated geomorphic and habitat assessment was used at the eight reaches on Underwood Creek and the Menomonee River (fig. 1, table 1). Two reaches are a restored and unrestored pair (sites 4 and 5, respectively) on Underwood Creek that are routinely measured as part of USGS ecological surveys. Site 8 (0408708565) was added after most of the other assessment sites and river walk-though were completed because of the presence of a large culvert with perennial flow entering Underwood Creek between site 1 and the location of the proposed point of return flow found during the river walkthrough (fig. 1).

The USGS had been using the USGS NAWQA habitat protocol (Fitzpatrick and others, 1998) to evaluate geomorphic and habitat conditions at 14 stream sites in the larger MMSD planning area where ecological data are collected (Eikenberry and others, 2010). The NAWQA protocol is very similar to the Wisconsin Department of Natural Resources transect-based habitat protocol (Simonson and others, 1994) and U.S. Environmental Protection Agency's (EPA) wadeable stream habitat 
Table 1. List of eight reaches included in the Underwood Creek geomorphic and habitat assessment study, 2012. These reaches included an integrated geomorphic and habitat assessment, discharge and water temperature measurements, and surveyed channel cross sections and longitudinal profiles.

[USGS, U.S. Geological Survey; nr, near; Cr, Creek; Wis., Wisconsin; NAWQA, National Water Quality Assessment]

\begin{tabular}{|c|c|c|c|c|c|c|}
\hline $\begin{array}{c}\text { Map } \\
\text { number }\end{array}$ & Latitude & Longitude & $\begin{array}{c}\text { USGS site } \\
\text { identification } \\
\text { number }\end{array}$ & Station name & Location & Channel type \\
\hline 1 & $43^{\circ} 02^{\prime} 22.92^{\prime \prime}$ & $-88^{\circ} 04^{\prime} 36.12^{\prime \prime}$ & 0408708562 & $\begin{array}{l}\text { Underwood Creek at Wall } \\
\text { Street at Elm Grove, Wis. }\end{array}$ & $\begin{array}{l}\text { Upstream of Waukesha } \\
\text { return flow }\end{array}$ & $\begin{array}{l}\text { Natural with some } \\
\text { stabilization. }\end{array}$ \\
\hline 2 & $43^{\circ} 02^{\prime} 00.95^{\prime \prime}$ & $-88^{\circ} 04^{\prime} 06.60^{\prime \prime}$ & 0408708575 & $\begin{array}{l}\text { Underwood Cr tributary } \\
\text { nr Ripley Avenue at } \\
\text { Brookfield, Wis. }\end{array}$ & $\begin{array}{l}\text { Upstream of Waukesha } \\
\text { return flow }\end{array}$ & Concrete lined. \\
\hline 4 & $43^{\circ} 03^{\prime} 03.95^{\prime \prime}$ & $-88^{\circ} 02^{\prime} 48.48^{\prime \prime}$ & 04087088B & $\begin{array}{l}\text { Underwood Cr at Wauwa- } \\
\text { tosa, Wis. }\end{array}$ & $\begin{array}{l}\text { USGS streamgage } \\
\text { (NAWQA Reach B- } \\
\text { Restored) }\end{array}$ & Rehabilitated. \\
\hline 5 & $43^{\circ} 03^{\prime} 29.88^{\prime \prime}$ & $-88^{\circ} 02^{\prime} 05.99^{\prime \prime}$ & 04087088A & $\begin{array}{l}\text { Underwood } \mathrm{Cr} \text { at } \\
\text { Wauwatosa, Wis. }\end{array}$ & $\begin{array}{l}\text { Downstream of } \\
\quad \text { streamgage (NAWQA } \\
\text { Reach A-Concrete) }\end{array}$ & $\begin{array}{l}\text { Concrete lined } \\
\text { and natural. }\end{array}$ \\
\hline 7 & $43^{\circ} 03^{\prime} 25.55^{\prime \prime}$ & $-88^{\circ} 01^{\prime} 46.92^{\prime \prime}$ & 04087092 & $\begin{array}{l}\text { Menomonee River at Hoyt } \\
\text { Park at Wauwatosa, Wis. }\end{array}$ & $\begin{array}{l}\text { Downstream of confluence } \\
\text { with Underwood Creek }\end{array}$ & Mostly natural. \\
\hline 8 & $43^{\circ} 02^{\prime} 13.56^{\prime \prime}$ & $-88^{\circ} 04^{\prime} 11.99^{\prime \prime}$ & 0408708565 & $\begin{array}{l}\text { Underwood Cr nr Blue } \\
\text { Mound Road at Elm } \\
\text { Grove, Wis. }\end{array}$ & $\begin{array}{l}\text { Upstream of confluence } \\
\text { with South Branch } \\
\text { Underwood Creek }\end{array}$ & Mostly natural. \\
\hline
\end{tabular}


USGS 04087088 Underwood Creek at Wauwatosa, Wis.

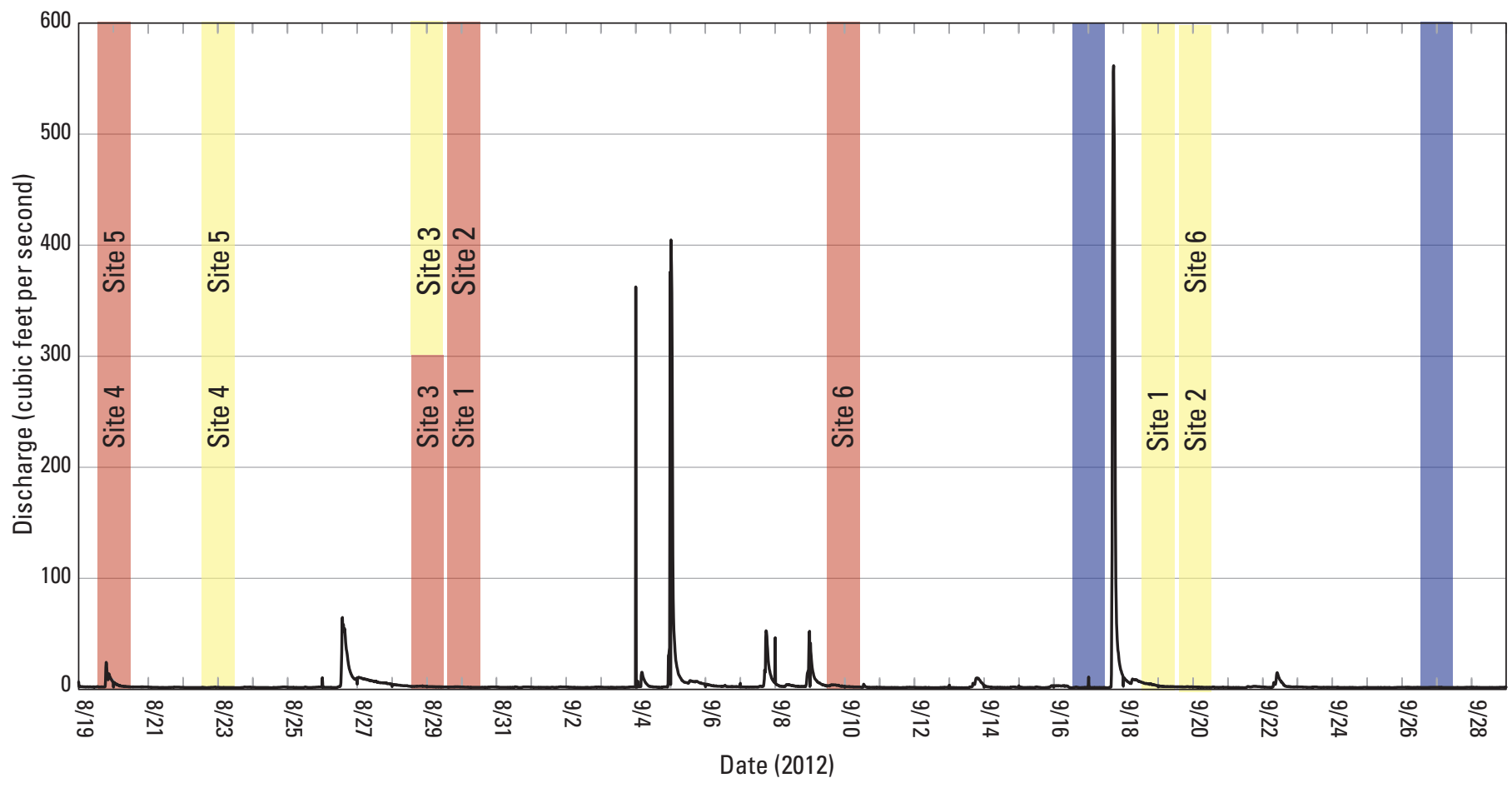

USGS 04087120 Menomonee River at Wauwatosa, Wis.

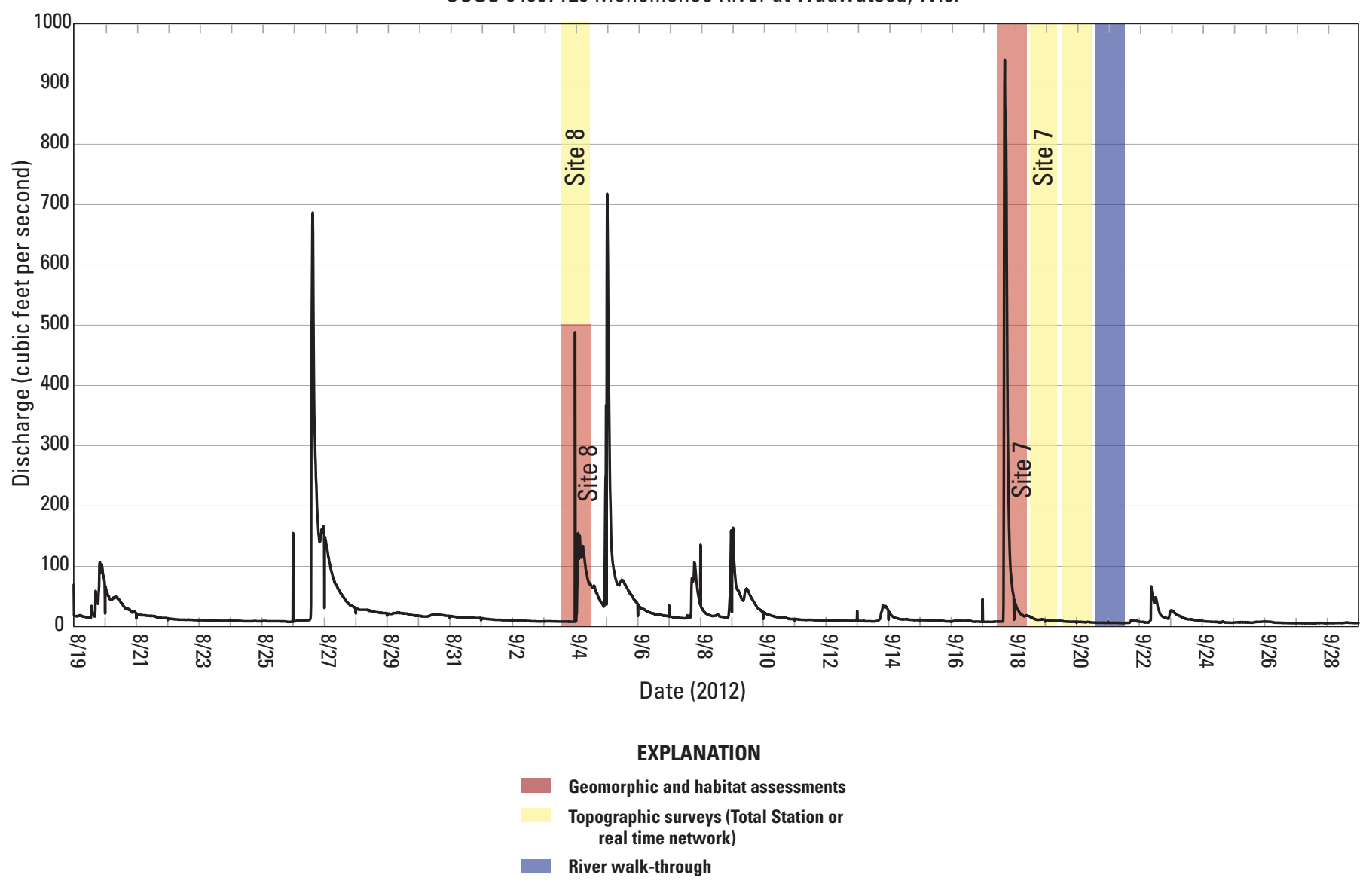

Figure 2. Hydrographs of $(A)$ Underwood Creek and $(B)$ Menomonee River with overlays of time periods when geomorphic and habitat assessments, river walk-through, and channel cross-section surveys and longitudinal profiles were completed. 
Stream Geomorphic and Habitat Data from a Baseline Study of Underwood Creek, Wisconsin, 2012
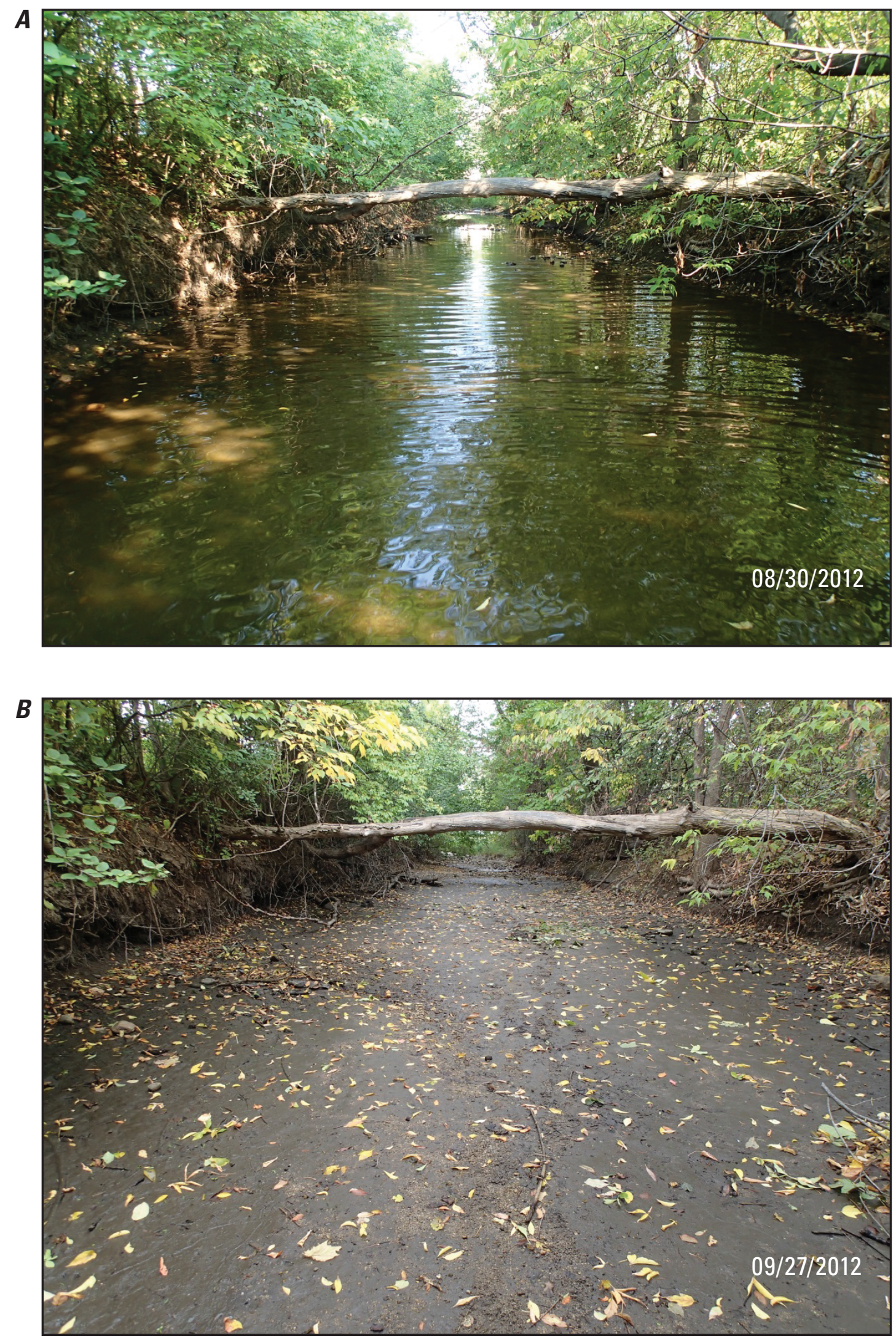

Figure 3. Comparison of flow conditions at Underwood Creek site 1 (0408708562) at time of geomorphic and habitat site assessment ( $A$ ) on August 30, 2012, at time of river walk-through, and (B) on September 27, 2012. 
assessments (Lazorchak and others, 1998; Kaufman and others, 1999; EPA, 2004, 2013). Measurements added to the USGS NAWQA habitat protocol included additional quantitative data for substrate characterization (pebble counts); bank erosion; fine sediment deposition; depositional bars; large woody debris; pools; lateral floodplain connectivity; riparian, floodplain, and valley conditions; rehabilitation techniques; and stream alterations (tables 2-5). These features were added to the protocol based on findings from a previous urbanization study conducted by the USGS in eight metropolitan areas across the United States that indicated more quantitative data are needed to evaluate urban streams in terms of success of stream rehabilitation projects (Fitzpatrick and Peppler, 2010). Some of the features are measured along the existing 11 transects, some are measured at added subtransects, similar to the EPA methods, and others are measured along the entire reach. Regardless of the number of transects, the sampled reach length was $150 \mathrm{~m}$ for all eight geomorphic and habitat assessment sites studied, which was similar to existing protocols that require a minimum distance of $150 \mathrm{~m}$ for habitat and fish assessments.

Quantitative measurements for eroding banks, depositional bars, large woody debris, and pools were completed for the reach at each geomorphic and habitat assessment site (table 2). These methods are more representative than those recorded at only transects because they encompass the entire reach. For all eroding banks (with an area greater than 0.5 square meter), the location, height, length, vertical extent, and predominant mechanism were recorded along both sides of the channel within the geomorphic and habitat assessment reaches as well as along the entire 10-km length of the river walk-through. This method was adopted from sediment budget techniques (Reid and Dunne, 1996, 2003; Fitzpatrick and others, 1999; Trimble, 2009). The volume of sediment in unvegetated depositional bars was also measured. Accumulated volume of soft fine-grained sediment (silts and clays) were estimated by measuring the width, length, and average thickness of soft sediment deposits with a measuring tape and metric ruler. The methods were adopted from Lisle and Hilton (1992) for measuring highly mobile fine sediment in pools that accumulates between runoff events. These measurements were collected for any deposit larger than $0.3 \mathrm{~m} \times 0.3 \mathrm{~m}$. In low gradient streams in the Milwaukee area, soft sediment deposits may span beyond pools and sometimes can cover entire reaches, burying gravel substrates. These deposits have a high water content and their thicknesses were determined by locating a hard bottom elevation that would support a human while wading. The areal extent (location and midpoint length and width) of unvegetated sand bars above the low-flow water level was also recorded.

Large woody debris and pool measurements were completed with techniques previously used for geomorphic and habitat assessments of Duluth, Minnesota, streams (Fitzpatrick and others, 2006). These two measurements are important indicators in Midwest streams for the success of habitat improvement or stream restoration projects.

A subset of measurements from a modified version of Thorne's (1998) rapid geomorphic assessment was also recorded for each of the eight reaches. Included were observations and average measurements for the entire reach (table 3) that had been previously used for urban stream geomorphic assessments in the Duluth, Minn., area (Fitzpatrick and others, 2006).

Transect based measurements were included in addition to the updated NAWQA reach based geomorphic and habitat assessment. At transect endpoints, information was collected about floodplain connectivity, dominant riparian land use and bank conditions (including total bank heights), bank toe water depths, rooting depth of vegetation on top of the bank, and root density (table 4). These features help to describe the erodibility of the banks.

Table 2. Detailed geomorphic measurements collected in addition to the National Water Quality Assessment protocol for Milwaukee Metropolitan Sewerage District geomorphic and habitat assessment at the eight sampled reaches along Underwood Creek and the Menomonee River. These area measurements and counts are for the entire reach.

\begin{tabular}{lc}
\hline \multicolumn{1}{c}{ Measurement } & Description \\
\hline Bank erosion & $\begin{array}{c}\text { Location, height, length, extent (none, toe, upper, whole), and predominant mechanism (fluvial/ } \\
\text { flow, piping, mass wasting, cattle). }\end{array}$ \\
Depositional bars and deposits & Location, width, length, thickness of soft sediment, substrate type, and additional notes. \\
Large woody debris & $\begin{array}{c}\text { Type, length, diameter, function (pool scour, bank stability, bar stabilizer, sediment trap, step } \\
\text { former), and source (slope, upstream, bank, unknown). }\end{array}$ \\
Pools & Length, width, depth, and source (free, large woody debris, bedrock/boulder/bank forced). \\
\hline
\end{tabular}


Table 3. Rapid geomorphic assessment measurements collected in addition to the National Water Quality Assessment protocol for Milwaukee Metropolitan Sewerage District geomorphic and habitat assessment at the eight sampled reaches along Underwood Creek and the Menomonee River. These measurements are estimated for the entire reach length

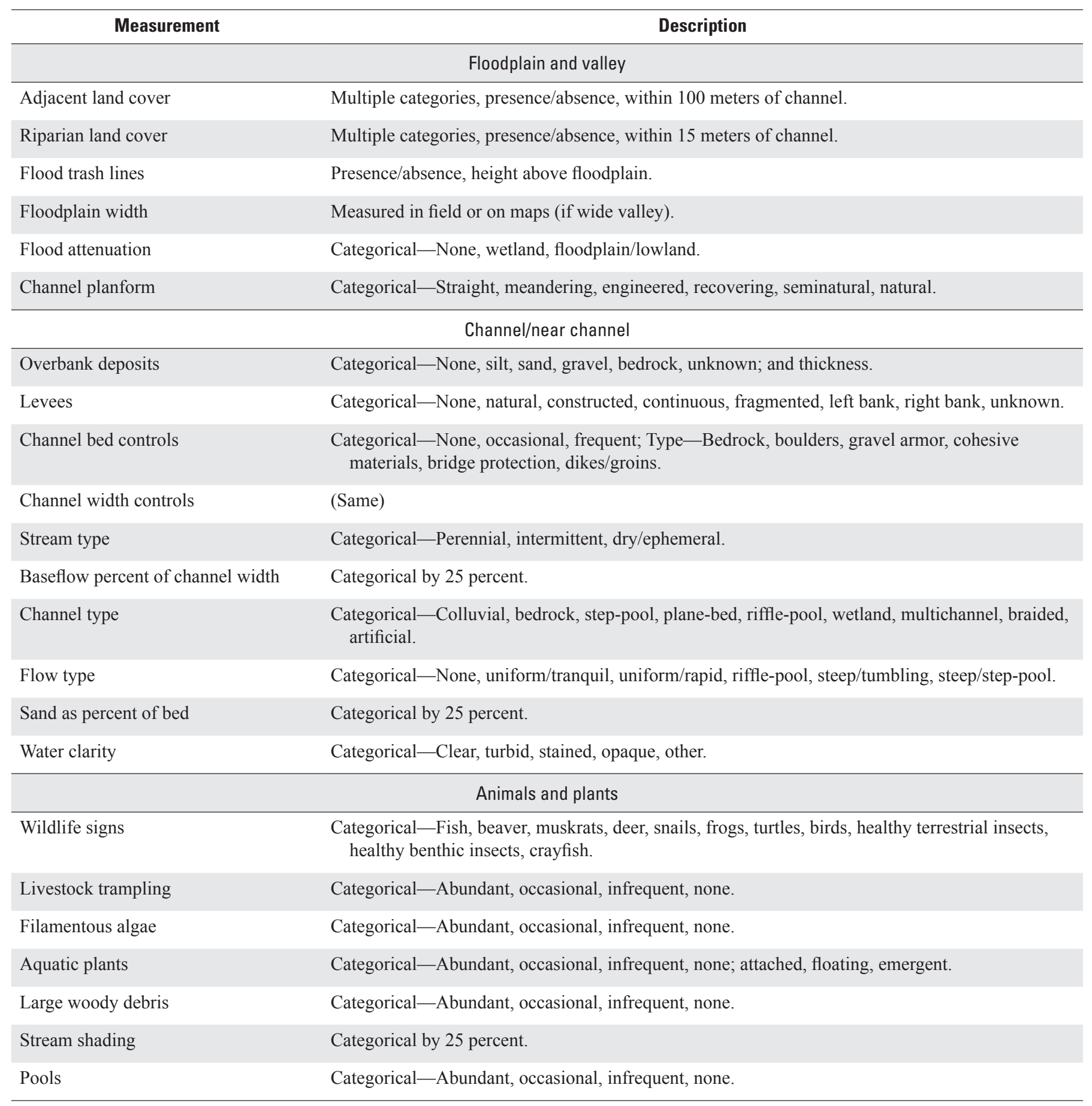


Table 4. Detailed geomorphic measurements collected in addition to the National Water Quality Assessment Program protocol for Milwaukee Metropolitan Sewerage District geomorphic and habitat assessment at the eight sampled reaches along Underwood Creek and the Menomonee River. These measurements are added to existing transect endpoints where other bank information is collected.

\begin{tabular}{ll}
\hline \multicolumn{1}{c}{ Measurement } & \multicolumn{1}{c}{ Description } \\
\hline Total bank height & From channel bed at bank toe to top of bank. \\
Bank toe water depth & From channel bed to water surface at bank toe. \\
Rooting depth & Vertical depth of roots from land surface downward. \\
Root density & Compactness of roots along exposed bank surface. \\
\hline
\end{tabular}

Table 5. Substrate-related measure-

ments collected at the 11 transects and

10 subtransects along the 8 sampled

reaches as part of pebble counts.

\begin{tabular}{l}
\hline \multicolumn{1}{c}{ Measurement } \\
\hline Soft sediment thickness. \\
Particle size of soft sediment. \\
Particle size of hard surface. \\
Silt coating. \\
Macrophyte presence. \\
Riprap. \\
Wet/dry water depth. \\
\hline
\end{tabular}

For substrate pebble counts (table 5), a grid system was adopted with equidistant spacing along 11 transects and $10 \mathrm{sub}$ transects and 5 points along each transect, for a total of 105 points. A tape was strung across the channel perpendicular to flow direction with a meter stick held vertically to mark the exact point along the tape for selecting the particle to measure. This was done to ensure objectivity in selection of the particle to be measured by the observer. The pebble count grid also was used to measure soft sediment thickness at the 105 points. A gravelometer was used to measure particle size of gravel and larger sizes (Bunte and Abt, 2001). A sand card was used to measure silt/clay through very coarse sand. At each point, notes indicated, if present, a light coating of silt, macrophytes, or riprap. The pebble count was kept within the bounds of channel-bed materials but sampled both dry and wet areas. Points that had a dry channel bed were noted; at wet points, water depth was noted. The data were recorded in a format that represents a map of the reach, so that over time the changes can be tallied and spatially noted. 


\section{River Walk-Through}

A reconnaissance-level river walk-through was conducted during low (or no)-flow conditions in August and September 2012 from the confluence of Underwood Creek and the Menomonee River to the proposed return-flow location and proceeded upstream beyond Underwood Creek at Watertown Plank Road (fig. 1). The river walk-through continued upstream along the South Branch Underwood Creek to where the channel flows underground near W. Greenfield Avenue. The river walk-through included the Menomonee River for approximately $1.15 \mathrm{~km}$ (Center Road) and $0.6 \mathrm{~km}$ (N. Swan Boulevard) upstream and downstream of the confluence with Underwood Creek, respectively.

USGS rapid geomorphic assessment protocols (Fitzpatrick and others, 2006) were used as a guide for the river walk-through, concentrating on changes in channel bed and bank stability, channel shape and size, flow, sediment and riparian conditions, deposition and erosion, and infrastructure. Photographs were collected with a global positioning system (GPS) camera noting areas of concern in terms of channel stability and changes in channel conditions. A handheld GPS was used to georeference those areas of channel stability concern and changing channel conditions, and notes were recorded in instances where no picture was taken. Components of interest included the following:

- channel type and alterations - concrete bottom, concrete sides, concrete bottom but floodplain at sides, natural channel, and (or) underground;

- channel morphology - major changes in wetted width and depth, bankfull width, size of concrete channel;

- dominant bedform — riffle/run/pool sequences, plane bed, concrete bed, steps;

- dominant planform - meandering, straight, channelized;

- amount of flow-points where the flow noticeably increases or decreases; point at which there is intermittent or discontinuous pools, to dry conditions;

- bed substrate - general categories (clay, gravel, sand, cement, riprap); reaches with silt deposition or major changes in bed slope;

- aquatic vegetation, algae, amount of woody debris, trash;

- fish or any other notable biotic activity;

- banks - changes in height, vegetation type, material, type of bank stabilization;
- depositional bars - amount of depositional bars and their general sediment size; potentially have some sections of concrete lined with vegetated depositional benches;

- riparian corridor - trees (falling in or leaning) shrubs, residential homes and yards, commercial properties, roads, pathways, and so forth;

- floodplain width; and

- water depth/amount of flow.

Additionally, the location of the following features were noted and recorded in the river walk-through:

- channel inputs - outfalls, drainage channels, downspouts, pipes, and culverts; type, diameter, flow, condition, material, height above channel bed, and any erosion/failure issues were all noted;

- channel crossings that may impede width or depth: road, pedestrian, railroad, and parking lot; type, if confining or not, and functioning as bed control were all noted;

- channel grade controls - weirs, rock drops, and anthropogenic; type, height, material, and condition were all noted;

- location of erosion (scour pool or bank) and deposition (island or bar); type, form, bank location, width, length, depth, and substrate (if necessary) were all noted; and

- infrastructure failure - crumbling cement, large blocks, and pieces of storm sewer pipe laying in the channel or a large drop between the storm sewer and channel.

\section{Discharge and Temperature Measurements}

Low-flow discharge and water temperature were measured and recorded at the eight geomorphic and habitat assessment reaches. Discharge was measured using a Sontek FlowTracker® during low flow in a location free of debris or any disruptions to flow (turbulence caused by substrate, rocks in channel, or logs, pools, and so forth) and usually in the middle of each respective reach. Water temperature was measured using a digital thermometer and recorded. Discharge and temperature were measured and recorded all on one day (August 30,2012) at each of the eight geomorphic and habitat assessment-site reaches. 


\section{Channel Cross-Section Surveys and Longitudinal Profiles}

At each of the eight reaches where geomorphic and habitat assessments were conducted, channel topographic cross sections and a longitudinal profile were surveyed. A combination of electronic total station and real time network (RTN) survey grade GPS was used, depending on overhanging vegetation cover that may interfere with and thus affect obtaining a fixed location needed for GPS positions. For channel cross sections, topographic survey points included the top of banks, bankfull, channel toe, and thalweg at a subset of transects from geomorphic and habitat assessment reaches. Sometimes a subset of the 11 transects was surveyed if there were no noticeable changes in channel dimensions throughout the reach (mostly in the case of concrete lined reaches). For the longitudinal profile, topographic survey points included thalweg and water surface at an interval of at least every channel width or where there were fluctuations or breaks in slope of the channel bed.

Horizontal and vertical data from the total station have an accuracy of approximately $0.005 \mathrm{~m}$. The RTN GPS has a horizontal and vertical accuracy of approximately 0.01 and $0.015 \mathrm{~m}$ respectively. Metal capped $1 / 2$-inch reinforcement bars were used to permanently mark cross section endpoints where possible.

\section{Stream Geomorphology and Habitat Data}

The geomorphic and habitat assessment site data were assembled into scans of field forms, electronic spreadsheets, and a geographic information system (GIS) map package using ESRI ArcMap Version 10.0. Complete rapid geomorphic assessment field forms were scanned. Georeferenced photos were included in a Picasa data set, along with a Picasa executable file. Picasa is image viewing software that allows users to view locations of georeferenced photos on a map. A subset of habitat-specific data collected during the baseline study can be retrieved through USGS BioData (https://aquatic.biodata.usgs. gov/landing.action), which is an online data retrieval system that allows users to select and download data in one zipped file. The following sections describe the data files.

\section{Completed Field Forms}

The Completed Field Forms folder contains Adobe portable document format (PDF) scans of completed field forms of geomorphic and habitat assessment data collected at the eight reaches. Field forms describe site, floodplain and valley attributes, channel and near channel attributes, bank erosion location and size, depositional bar size, animal and plant presence, large woody debris and pool measurements, an overall reach characterization, diagrammatic reach map, pebble count and substrate data transect (11 per site) habitat characterization, and site picture descriptions. It is worth noting that the pebble count data for site 5 was misplaced, so data collected at the same reach from 2011 have been substituted for the missing 2012 pebble count data. Also within the Completed Field Forms are three PDF files of electronic scans of field book notes from the river walk-through assessment.

\section{Data Tables}

The DataTables folder contains data organized into Microsoft Excel spreadsheet tables for both the geomorphic and habitat assessments and the river walk-through. It should be noted that some headers in these data tables are abbreviated in order to be entered into GIS (10 character header maximum). Also, it is worth noting that unique identification numbers found in each data set are unique only for that respective data set, so there maybe duplicate unique identification numbers among multiple data sets. Data tables include the following:

USGS_UnderwoodCreek_ChannelCrossings.xIsx contains the location and type of channel crossings identified during the river walk-through, whether each channel crossing is acting as a confining influence on the channel, and whether it is acting as a bed control.

USGS_UnderwoodCreek_ChanneIDimensions.xIsx contains channel dimensions of Underwood Creek (wetted width, bankfull width, bankfull depth) where applicable. Most channel dimensions were measured at the 8 geomorphic and habitat assessment sites along 11 transects throughout the reach. However, some channel dimensions are from the river walk-through. Null data for site and transect number indicate data measured during the river walk-through assessment. Null data for wetted widths, bankfull widths and bankfull depths throughout the river walk-through assessment indicate respective dimensions were not measured at that time.

USGS_UnderwoodCreek_Channellnputs.xIsx contains the location, type, size (diameter), flow conditions, condition, material, and height above channel if applicable of all inputs to the channel located during the river walk-through. Typical channel inputs were outfalls (elevated point above channel discharging into channel), drainage channel (distinct channel, natural or concrete lined, that drains directly into the main channel), drain (seepage point draining directly into channel), downspout (vertical pipe draining from roadway or crossing, usually elevated above channel), pipe (obvious hollow cylinder draining directly into channel), and culvert (channel flows below a restricted crossing).

USGS_UnderwoodCreek_ConcreteFailures.xIsx contains the location of all concrete failures found during the river walk-through assessment.

USGS_UnderwoodCreek_DischargeAndTemperature. $\mathbf{x I s x}$ contains the instantaneous measured discharge and the date, time, and mean stream temperature at the time of discharge measurement for each geomorphic and habit assessment site. 
USGS_UnderwoodCreek_ErosionDeposition.xIsx contains the coordinates, type, form, site map number, USGS station identification number and associated transect (if applicable), side of bank (left or right as looking downstream), size (width, length, depth in meters), and substrate of all deposition and erosion along entire river walk-through boundary, including data from the eight geomorphic and habitat assessment sites. Deposition consists of bar or island (form) and erosion consists of scour pool or bank erosion. Dimensions (width, length, depth) and associated substrate were measured and recorded for each depositional or erosional area, where applicable.

USGS_UnderwoodCreek_GPSlog.xIsx contains all GPS points and associated attributes collected during the river walk-through. No data are denoted in the table as ND.

USGS_UnderwoodCreek_GradeControls.xIsx contains the location, type, height above channel bed, material, and condition of grade control structures throughout the river walk-through boundaries.

USGS_UnderwoodCreek_ReachAndPebbleCounts.xIsx contains overall reach characteristics from the eight geomorphic and habitat assessment sites. The floodplain and valley tab describes general floodplain and valley characteristics present, whereas the channel and near channel tab describes channel and near channel characteristics present for each of the geomorphic and habitat assessment sites. The pebble count tab within the spreadsheet contains particle sizes for five points along transects and sub transects at seven of these sites. Again, because the pebble count data for site 5 were misplaced, data collected at the same reach from the previous year, 2011, were used as a substitute.

USGS_UnderwoodCreek_Riparian.xlsx contains the primary and secondary riparian land use along the left and right (looking downstream) banks at transect endpoints for the eight geomorphic and habitat assessment sites.

USGS_UnderwoodCreek_SiteList.xIsx contains a description of the eight geomorphic and habitat assessment site numbers, coordinate location of middle of the reach, USGS identification numbers, station name, location, channel type, and reach length.

USGS_UnderwoodCreek_Substrate.xlsx contains the dominant and secondary substrate of the channel, percent embeddedness by fines (three locations along transect), and silt depth (three locations along transect in centimeters) for each transect at the eight geomorphic and habitat assessment reaches. Null data for indicate respective substrate were not measured at that time.

\section{Photos}

The Photos folder contains photographs from the geomorphic and habitat assessment sites as well as those taken during the river walk-through. Descriptions and georeferenced locations were recorded in each photograph's properties in their JPG (Joint Photographic Experts Group) files, and the same data can also be viewed with Picasa software. Within the photos folder, there are two separate subfolders titled Geomorphic and Habitat Assessment Site Photos and River WalkThrough Photos. The Geomorphic and Habitat Assessment Site Photos folder contains all photographs from transects at the eight geomorphic and habitat assessment reaches. It should be noted that photographs do not always appear in the direction where the first transect of each reach is always the farthest downstream. The River Walk-Through Photos folder contains all photographs from the river walk-through and are organized by date taken and the initials of USGS personnel responsible for taking photographs. The individual reaches of the river walk-through assessment in which USGS personnel were responsible for are also noted in the ArcGIS map package. Personnel responsible for the photos are Nicolas H. Buer (NHB), Benjamin M. Young (BMY), and James D. Blount (JDB).

\section{Main Folder}

Picasa39-setup.exe is an executable file for Picasa, which is an image organizing and viewing software developed by Google. Picasa is one way to view georeferenced photographs from the river walk-through and eight geomorphic and habitat assessment sites, while at the same time seeing the photograph location plotted on a map. Once Picasa is installed, the user will have to add a folder (file>add folder to Picasa) and navigate to the file location where the photographs are stored.

USGS Underwood Creek_ReadmeFile.docx is a document describing the electronic files of data from the habitat and geomorphic assessment and river walk-through collected in summer and fall 2012 associated with the baseline study of Underwood Creek prior to the proposed Waukesha return flow.

USGS Underwood Creek Site Surveys-Cross Sections. xIsx is a Microsoft Excel spreadsheet of all raw and processed transect cross-section data collected from topographic channel surveys at the eight geomorphic and habitat assessment sites. Survey method is noted (whether survey-grade RTN GPS or total station was used) on each transect. Sites surveyed exclusively with the total station are required to begin the survey at the first occupy point in a local, arbitrary false northing, easting, and elevation unless "tied in" to true coordinates with a GPS. This initial occupy point in this case is set up with an arbitrary false northing value of $5,000 \mathrm{~m}$, an arbitrary false easting value of 5,000 $\mathrm{m}$ and an arbitrary false elevation of $100 \mathrm{~m}$ in order to ensure all collected data points are a positive value. Sites surveyed with the survey grade RTN GPS are collected in true coordinates and orthometric elevations. Therefore, cross sections surveyed with the total station will show a y-axis of height above datum (in false units) with values between 0 and $30 \mathrm{~m}$, whereas cross sections surveyed with RTN GPS will show a y-axis of elevation ranging from approximately 200-220 (MASL, meters above sea level).

Sites are separated by tabs running along the bottom of the 
spreadsheet. No cross-section data were collected at site 1 (0408708562) due to thick bank vegetation, steep banks, and high water during time of topographic survey.

USGS Underwood Creek Site Surveys-Longitudinal

Profiles.xIsx is a Microsoft Excel spreadsheet of all raw and processed longitudinal profile data collected from topographic channel surveys at the eight geomorphic and habitat assessment sites to better understand channel slope. Longitudinal profiles consisted of points collected along the thalweg and water surface usually at every major break in slope or every few feet if there was no distinct change in slope. Longitudinal profiles often extend past the $150 \mathrm{~m}$ of standard reach length. Survey method is noted (whether survey grade RTN GPS or total station was used) on each geomorphic and habit assessment site longitudinal profile. Again, different survey methods will result in different $y$-axis range of values on graphs as noted in previous section.

USGS_UnderwoodCreekReturnFlowStudy.mpk is a map package created using ArcMap version 10.0, which contains all the geospatial data compiled from the geomorphic and habitat assessment sites and river walk-through, as described above in the data tables. An ArcMap map package is a map document where all referenced data sources are compressed into a single file and allows users to view geospatial data. Users working in ArcMap version 10.0 or newer can readily open the map package. Users with older versions of ArcMap or with open-source GIS software packages can access the constituent data by unzipping the map package file to reveal the constituent data, from which an analogous map file can be constructed. Layers within the map package include a site list, channel crossings, channel dimensions, channel inputs, concrete failures, erosion and deposition, river walk-through GPS log, grade controls, riparian conditions, RTN topographic survey data, dominant streambed substrate categories, river walk-through boundaries, bank erosion, bank protection, channel bed type, USGS river walk-through personnel, and base maps of aerial imagery and streets.

\section{Summary}

In cooperation with the Milwaukee Metropolitan Sewerage District (MMSD), the U.S. Geological Survey collected geomorphic and habitat data along Underwood Creek and Menomonee River to characterize baseline conditions of Underwood Creek prior to a potential discharge of wastewater effluent from Waukesha, Wis. The purpose of this study is to not only document baseline geomorphic and habitat conditions of Underwood Creek prior to this possible discharge, but also to document conditions for potential rehabilitation work by MMSD. The methods used and data collected are presented in this report. Geomorphic and habitat data, along with topographic channel cross sections and longitudinal profiles, were collected from August to October 2012 in order to document baseline conditions at two different spatial scales.
Transect-based reach-scale data were collected at eight geomorphic and habitat assessment sites and were complimented by approximately a 10-kilometer thorough river walk-through that spanned the eight geomorphic and habitat assessment sites. Data are presented in the form of scanned rapid geomorphic assessment forms and field notes, data tables, transect cross-sectional and longitudinal topographic profiles, georeferenced photographs, and a map package that allows users to view the vast majority of these data spatially. The data from this report will be used by MMSD in the future to make best management decisions on stream restoration and return flow of Underwood Creek and further address overall water-quality issues in the greater Milwaukee metropolitan area.

\section{References Cited}

Bunte, K., and Abt, S.R., 2001, Sampling surface and subsurface particle-size distributions in wadable gravel- and cobble-bed streams for analyses in sediment transport, hydraulics, and streambed monitoring: U.S. Department of Agriculture, U.S. Forest Service, Rocky Mountain Research Station, General Technical Report RMRS-GTR-74, 428 p.

CH2M HILL, 2013, Application summary, City of Waukesha Application for a Lake Michigan diversion with return flow: City of Waukesha, v. 1, October 2013, 78 p.

Eikenberry, B.C.S., Bell, A.H., Sullivan, D.J., Lutz, M.A., and Alvarez, D.A., 2010, Biological water-quality assessment of selected streams in the Milwaukee Metropolitan Sewerage District Planning Area of Wisconsin, 2007: U.S. Geological Survey Scientific Investigations Report 2010-5166, 28 p.

Fitzpatrick, F.A., Knox, J.C., and Whitman, H.E., 1999, Effects of historical land-cover changes on flooding and sedimentation, North Fish Creek, Wisconsin: U.S. Geological Survey Water-Resources Investigations Report 99-4083, 12 p.

Fitzpatrick, F.A., and Peppler, M.C., 2010, Relation of urbanization to stream geomorphic and habitat characteristics in nine metropolitan areas of the United States: U.S. Geological Survey Scientific Investigations Report 2010-5056, 29 p.

Fitzpatrick, F.A., Peppler, M.C., DePhilip, M.M., and Lee, K.E., 2006, Geomorphic characteristics and classification of Duluth-area streams, Minnesota: U.S. Geological Survey Scientific Investigations Report 2006-5029, 54 p.

Fitzpatrick, F.A., Waite, I.R., D’Arconte, P.J., Meador, M.R., Maupin, M.A., and Gurtz, M.E., 1998, Revised methods for characterizing stream habitat in the National Water-Quality Assessment Program: U.S. Geological Survey WaterResources Investigations Report 98-4052, 67 p. 
Kaufman, P.R., Levine, P., Robison, E.G., Seeliger, C., and Peck, D.V., 1999, Quantifying physical habitat in wadeable streams: Washington, D.C., U.S. Environmental Protection Agency EPA/620/R-00/003.

Lazorchak, J.M., Herlihy, A.T., and Green, J., 1998, Rapid habitat and visual stream assessments, section 14 of Lazorchak, J.M., Klemm, D.J., and Peck, D.V., eds., EMAP - Surface waters - Field operations and methods for measuring the ecological condition of wadeable streams: Washington, D.C., U.S. Environmental Protection Agency EPA/620/R-94/004F.

Lisle, T.E., and Hilton, S., 1992, The volume of fine sediment in pools - An index of sediment supply in gravel-bed streams: American Water Resources Association Water Resources Bulletin, v. 28, no. 2, p. 371-383.

Reid, L.M., and Dunne, T., 1996, Rapid evaluation of sediment budgets: Catena Verlag, Reiskirchen, 164 p.

Reid, L.M., and Dunne, T., 2003, Sediment budgets as an organizing framework in fluvial geomorphology, in Kondolf, G.M., and Piegay, H., Tools in fluvial geomorphology: New York, Wiley, p. 463-500.

Simonson, T.D., Lyons, J., and Kanehl, P.D., 1994, Guidelines for evaluating fish habitat in Wisconsin streams: St. Paul, Minn., U.S. Department of Agriculture, U.S. Forest Service, North Central Experiment Station General Technical Report NC-164.
Thomas, J.C., Lutz, M.A., Bruce, J.L., Graczyk, D.J., Richards, K.D., Krabbenhoft, D.P., Westenbroek, S.M., Scudder, B.C., Sullivan, D.J., and Bell, A.H., 2007, Water-quality characteristics for selected sites within the Milwaukee Metropolitan Sewerage District Planning Area, Wisconsin, February 2004-September 2005: U.S. Geological Survey Scientific Investigations Report 2007-5084, 187 p.

Thorne, C.R., 1998, Stream reconnaissance handbook: Chichester, West Sussex, England, Wiley, 133 p.

Trimble, S.W., 2009, Fluvial processes, morphology and sediment budgets in the Coon Creek Basin, WI, USA, 19751993: Geomorphology, v. 108, p. 8-23.

U.S. Environmental Protection Agency (EPA), 2004, Wadeable stream assessment, field operations manual: Washington, D.C., U.S. Environmental Protection Agency, Office of Water and Office of Research and Development EPA-841-B-04-004.

U.S. Environmental Protection Agency (EPA), 2013, National rivers and streams assessment 2013-2014, field operations manual-Wadeable: Washington, D.C., U.S. Environmental Protection Agency, Office of Water EPA-841-B-12-007.

U.S. Geological Survey, 2013, Water-resources data for the United States, water year 2012: U.S. Geological Survey Water-Data Report WDR-US-2012, site 04087088, accessed at http://wdr.water.usgs.gov/wy2012/pdfs/04087088.2012. pdf. 

